\title{
RIIK RÄÄGIB RAHVALE: SOOMEKEELSED KORRALDUSED ROOTSI AJAL
}

\author{
Kari Tarkiainen \\ Soome Riigiarhiiv, Helsingi
}

\begin{abstract}
Ülevaade. Kuningas ja lääniülemad avaldasid Rootsis 16. saj alates korraldusi, mida levitati kas rahvakoosolekutel või kirikukantslist ette lugedes. See tava kodifitseeriti 1686. a kirikuseadusega. Korralduste ettelugemine muutus jumalateenistuse osaks ja nende kuulamine oli kõigile kohustuslik. Kuna riigi idaosas Soomes ei osatud rootsi keelt, hakati korraldusi soome keelde tõlkima, mistõttu Rootsi võimuperioodi lõpuks moodustasid sellised tekstid umbes neljandiku kõikidest korraldustest. Selle süsteemi tugisammasteks muutusid Kantseleikolleegiumi juures tegutsenud soomendajad ja kuninglik trükikoda, kellel oli korralduste publitseerimise privileeg. Tekstidest olid kõige tähtsamad 3-4 korda aastas esitatud palvepäevaplakatid, mis sisaldasid aktuaalseid uudiseid kõnealuse kirikupüha jaoks Piibli tekstide valguses. Korraldusi trükiti 17. saj enamasti Turus, kuid 18. saj peamiselt Stockholmis.

Korralduste tekstidel on varasemal ajal arvatud olevat suhteliselt vähene tähendus soome kirjakeele arengule, mis hakkas 19. saj kulgema purismi suunas, loobudes tollases kultuurkeeles tavalistest rootsipärasustest. Uuemad vana soome kirjakeele uurimused näitavad siiski, et kuulmise järgi omandatud ning tõlkijate loodud uudissõnu ja neologisme oli rahvakeelde kandunud üsnagi suurel määral ja sedakaudu siirdusid nad ka tänapäeva soome keelde. Nõudlus soomekeelsete tekstide järele riigi idaosas ei näita 16.-18. saj mitte soomlaste rahvustunnet, vaid selle aluseks oli hoopis vajadus tagada kõikide inimeste võrdsus seaduse ees. Korraldustel oligi suur ühiskondlik tähtsus laiade rahvakihtide õigustaju arenemise ja seadustetundmise lisandumise seisukohast.
\end{abstract}

Märksõnad: Rootsi seadusandlus, tõlkimine, soome vana kirjakeel, neologismid, palvepäevaplakatid, jumalateenistuse kulg, rahva distsiplineerimine

DOI: https://doi.org/10.12697/jeful.2017.8.1.15

\section{Objekt või subjekt?}

Käesolevas uurimuses võetakse vaatluse alla olud Rootsis ja Soomes (provintsid, mh ka Eestimaa ja Liivimaa on jäänud käsitlusest 
välja) ning keskendutakse ühele teavitamise vormile - avalikele korraldustele $^{1}$ - varauusajal, täpsemalt ajavahemikul 16.-18. saj. Valitsusorganid koostasid neid tekste rahvale kuulamiseks. Enne kui asuda neid tekste vaatlema ajaloo vaatenurgast, on aga siiski vaja lühidalt esitleda selle nähtuse tausta.

Vanem uurimus on üldiselt pidanud ühtset rahvast valitsemise objektiks, kes võttis passiivselt vastu ülevalt tulevad käsud. Ajalugu on sel põhjusel keskendunud eelkõige ühiskonna ülemkihi tegevuse kirjeldamisele. Uuem uurimus seevastu ei ole omaks võtnud käsitlust rahva passiivsest rollist. Rahvast on hakatud üha enam pidama subjektiks, omaette toimijaks eelkõige kohalikul tasandil. See tegevus on küll olnud väikesemõõtmeline ja mitte nii dramaatiline, kuid sel on olnud suur tähtsus kogu ühiskonnale.

On tähelepanuväärne fakt, et Rootsis oli vähe talupoegade ülestõuse, kuigi Euroopas oli neid 17. saj rohkesti. Ainuüksi Prantsusmaalt on ajavahemikust $1590-1715$ teada 450-500 rahvaülestõusu (Linde 2000: 17). Rahvas ei tõusnud Rootsis üles ligi paarisaja aasta jooksul. Seal kasutati omalaadseid, rahulikke vahendeid. Nendeks abinõudeks olid ühelt poolt oludega kohanemine (rts anpassning) ja teiselt poolt seaduslike protestide esitamine (protest). Just need sõnad on nt Nils Erik Villstrand (1992) pannud oma väitekirja "Anpassning eller protest" peakirjaks. Ta kasutab 17. saj talurahva olude kohta Rootsis ja Soomes huvitavat nimetust - pärsitud ülestõus (rts det inhiberade upproret). Ka mõned teised Põhjamaade uurijad on viimasel ajal olnud samadel seisukohtadel, kusjuures selle suuna juured on nii nagu ajaloouurimises üldisemaltki rahvusvahelised ja saanud alguse ameerika antropoloogi James C. Scotti seisukohtadest (Scott 1985, Kepsu 2014).

"Pärsitud ülestõus" on mõiste, mida Martin Linde on hiljuti edasi arendanud oma teoses "Statsmakt och bondemotstånd" (2000). Tema arvates oli pidevalt käiv sõda ülemkihi jaoks vahend, millega peeti rahvast kuulekana. Ähvardamine väljastpoolt tuleva ohuga, mis oli ühine kogu ühiskonnale, hoidis rahvast koos. Rahvas ja riik olid mõlemad huvitatud välisohtude tõrjumisest (Linde 2000: 13-17). Kuid ka selle uurija meelest oli Rootsi ühiskonnale iseloomulik hästi toimiv kohalik tasand, kus rahva rahulolematust oli võimalik leevendada.

Rootsi ühiskondliku rahu säilitamise jaoks oli kesksel kohal mõistagi rahva hoolikas teavitamine eri küsimustes. See tugines õiguslikul

1 Eestimaal nimetati selliseid korraldusi enamasti plakatiteks, Liivimaal patentideks, vt Eesti Rahvusarhiivi 17. saj trükiste andmebaas: www.ra.ee/plakatid/. 
arusaamal, et isik, kes ei tundnud seadusi ja korraldusi, ei võinud neid õigupoolest ka rikkuda või vähemalt oli seaduse mittetundmine kuriteo eest karistamisel leevendavaks teguriks. Ainult teo karistatavusest teadliku inimese kuritöö oli tegelik, kohtus kaalumisele võetav pahategu. Sellest lähtekohast sõltuvalt oli vältimatu tutvustada rahvale nii palju riigi seadusi ja korraldusi kui võimalik.

Rahva õpetamine ei olnud võimalik mingil muul moel kui suuliselt. Informatsioonikanaliteks olid keskajal ja 16. saj sagedased maakonnakoosolekud, härrasrahva koosolekud ja mitmesugused kohalikud koosviibimised, nagu nt laadapäevad, kus kuningas või tema esindajad seletasid ilukõne vormis, mida inimestelt nõutakse ja mil moel (lähemalt Renvall 1967: 56-89). Ka kärajad ehk kohtuistungid toimisid uudiste vahendamise foorumitena.

\section{Jumalateenistused riigi hääletoruna}

Luteri kirikust sai Rootsis ja Soomes 1530. aastatest alates lisaks eri tüüpi koosolekutele riigile sobiv informatsiooni vahendaja. Rahvas kogunes jumalateenistustele, kus ei enam olnud keskmes pidulik hardus ja müstika nagu keskajal, vaid õpetus ja Piibli tõdede kuulutamine. Jumalateenistuse kese siirdus altari eest osaliselt kantslisse, kust kirikuõpetaja rääkis rahvale. Kantsel paiknes tavaliselt kirikus kõrgemal ja sageli kasutati võrdlust, et sealt ülalt langesid hingekarjase sõnad rahva peale kui seemned põllule. Jutlustamise toon oli pidulik ja aeglane ning keelekasutus pidi olema rahvale omane. Nii nagu kogu Euroopas, tekkis ka Rootsis ja Soomes juba 16. saj kiriklik tõlkekirjandus. Jumalateenistusega liideti 16. saj ilmalik osa, mis haaras eri tüüpi korralduste ja teadete ettelugemist. Kirikuõpetaja seisis pärast jutlust edasi kantslis, kuid muutis oma hääle argisemaks, sest tema sõnum ei tuginenud enam pühadele tekstidele, vaid hoopis kuninga või lääniülema kantseleis koostatud korraldustele. Uute korralduste lugemine (ja mõnikord vanade kordamine) kestis umbes pool tundi, sest kuulajate tähelepanu oli sellest kauem raske köita. Korralduste ettelugemine oli jumalateenistuse osa, sest alles pärast seda loeti lõpupalve või toimus armulaud. Kõik koguduse liikmed pidid kogu jumalateenistuse vältel kohal olema. Üldine seisukoht oli, et kui rahvas oli korraldusi kuulnud, oli ta mõistnud ka nende sisu, mistõttu oli võimalik ka kuritöö toimepanemisel karistusi määrata.

Nii istus Rootsi riigi rahvas pühapäev pühapäeva järel kirikus, olgu väljas juulikuu palavus või veebruari pakane, kuid seda tehti küll 
enamasti meelsasti, kuigi rahva seas oli alati rahutuid, kes käisid sisse ja välja, võtsid kirikusse kaasa koera või käisid vahepeal külmarohtu rüüpamas (korralduste lugemise kohta Rootsis lähemalt Reuterswärd 2001, Villstrand 2006: 51-67). Peamine oli siiski see, et kõik said uudistest osa ning kuulutuste ja teadete esitamine kirikus sobis hästi tolle aja informatsioonivajaduse rahuldamiseks. Sel moel ei olnud kirik mitte ainult areen usuliste toimingute jaoks, vaid ka ilmaliku võimu keskus (Forssberg 2005: 62-64).

Korralduste vool aja jooksul paisus ning kirikuõpetajate suhtumine nende ettelugemisse ja sellele kulutatud aeg varieerus suuresti. Tähtsamad korraldused arhiveeriti, sidudes need suurteks väljaannete sarjadeks, mille kohta kasutati nimetust Arstrycktet. On mõõdetud, et nt Rootsi Riigiarhiivis, Svea õuekohtus ja Kammerkolleegiumis säilitatavate Kuningliku Majesteedi kvartformaadis korralduste köidetud sarjad, mis ulatuvad 16. saj kuni 1980. aastani, võtavad enda alla 25 riiulimeetrit. Sarjade vanemad osad kujutavad endast kohmakaid muhklikke nahkköiteid, mida hoiavad koos kanepist valmistatud nöörid, kuid mida aeg edasi, seda kaunimaks ja siledamaks need köited muutusid ja nende seljal võis üha rohkem näha helkivaid kuldseid kirjatähti (Tarkiainen 1980: 1-21). Kirikute ja alamate kohtuasutuste arhiividesse kogunenud korraldused jäid enamasti köitmata.

\section{Riigi huvi, rahva huvi}

Omaette liigi korralduste seas moodustavad nn palvepäeva plakatid (rts bönedagsplakaten). Nende teke on seotud Rootsile sobiva ideoloogia väljaarendamisega 17. saj alguses. Kolm või neli nädalavahetust aastas valiti erilisteks palvepäevadeks ja nende päevade jumalateenistuse tekstid avaldati enne korraldustena, mis olid mõeldud kantslist ettelugemiseks. Palvepäevaplakatite sõnum oli selgelt riigi poliitikat ülistav ja sündmusi kajastati kõnesoleva pühapäeva kirikutekstist lähtudes. Palvepäeva aade mõjutas oma laiahaardelise ja piduliku sõnumiga seda korraldust, milles Piibli maailm ja riigi idee ühinesid ühtseks tervikuks. Rahvas pidi palvetama, patte kahetsema, soovima kuningale ja riigile edu ning nende mõtele jõul üle elama rasked ajad, ikaldusaastad, nakkushaigused ja sõdade kaasatoodud kaotused ja kahjud. Inimese osa oli patukahetsus ja alistumine Jumala tahtele, mitte mässamine ja rahulolematus. Palvepäevadel oli suur ühiskonda liitev ja üksmeelsust loov jõud, mis oli riigile kasulik (Villstrand 2006: 56-58). 
Kirikus kuulutati ka kutset riigipäevale ja riigipäeva otsuseid ning kord aastas loeti ette kehtiv konstitutsioon. Kui riik sattus sõtta, selgitati selle põhjusi, kirjeldades vaenlase hirmutegusid. Kõik toimuv pandi usulisse seosesse erinevalt ajastu vähestest ajalehtedest, mille sisu oli täiesti ilmalik. Rahvas taipas juba kirikuõpetaja hääletoonist, kas loetav tekst hakkab puudutama rõõmsaid või kurbi sündmusi, teatama võidusõnumit või troonipärija sündimist või hoopis informeerima kaotusest või valitseja surmast. Rahval oli korralduste ettelugemisest ka otsest kasu. Nendes oli palju argipäeva nõuandeid, mida kuulati meelsasti. Saadi teada, kuidas jätta ametiasutustele kaebekirju, kuidas kustutada metsatulekahju, kuidas maksta makse ja millised teod olid karistatavad. Tähtsamatest korraldustest loodi erilisi ühendkooslusi, mida korrati aastast aastasse.

Rahvas oli väga huvitatud oma õiguste kuulamisest, kuid kohustusi ei tahetud sama innukalt teada. Oli tavaline, et inimesed teesklesid teadmatust, kui nad jäid mingi üleastumisega vahele. Nendel puhkudel, kui oli juba varem teada, et kirikus loetakse ette mingi ebameeldiv korraldus, jätsid nii mõnedki teadlikult sel päeval jumalateenistusele minemata. Juhtus sedagi, et kirikuõpetaja hääl uppus lärmi ja protestide sisse. See võis olla küll ka kiriku, mitte ainult riigi vastu suunatud trotsi väljendus. Üldisemalt vaadates tugevdas korralduste ettelugemine kirikus (kuigi see oli muidugi ühesuunaline, ülalt allapoole suunatud teavitus) ühiskonda ja selles valitsevat üksmeelt (Villstrand 2006: 58-63). See tegevus võeti üldiselt omaks ja selle keel muutis eri piirkondade rahvakeelt samalaadsemaks.

\section{Soomekeelsete korralduste varasem ajalugu}

Rootsi keel oli Soomes Rootsi ajal ainuke asjaajamiskeel (Lehtinen 1955: 394-396). Korralduste väljakuulutamine tekitas seal probleeme, ükskõik kas see toimus rahvakoosolekul, laatadel või kirikus. Kaks kolmandikku rahvast ei mõistnud rootsi keelt ja sel põhjusel pandi Turu piiskopkonnas varauusajal alus kiriklikule tõlkekirjandusele, mis sai alguse Mikael Agricola ilmselt 1543. a avaldatud tagasihoidliku aabitsaga ja saavutas kõrgpunkti kuninganna Kristiina ajal 1642. a trükitud suure ja uhke soomekeelse Piibliga. Nende verstapostide vahele mahtus suur hulk palveraamatuid, jutluste kogusid, katekismuseid ja lauluraamatuid. Seaduste tekstide puhul läks kõik palju konarlikumalt, sest nende avaldamist pidurdas üldine seaduste uuendamine 17. sajandil ja 
kuigi lõpuks 1759. a ilmus seaduseraamat soome keeles, ei saanud see kunagi sama õiguslikku jõudu kui rootsikeelne algtekst.

Riigile oli algusest peale selge, et soome talupoegadega on võimalik suhelda ainult soome keeles. Teade kuningas Gustav Vasa esinemise kohta Lohja kiriku hoovis 1555. a sügisel aitab sellele teemale valgust heita. Kuningas kirjutas sealt oma pojale, Soome hertsog Johanile, et rahvas ei kuulanudki sel korral teda tavalisel heatahtlikul moel, vaid "täitis ennast õllega, karjus ja lärmas meie enda juuresolekul nii, et keegi ei võinud midagi kuulda või neile rääkida" (Tarkiainen 2000: 130). Kuningas oli proovinud esineda lohjalastele rootsi keeles ja märkas liiga hilja, et kuulajaskond koosnes soomlastest, kes ei saanud tema kõnest midagi aru.

Ehk põhjustas just see sündmus muutuse Gustav Vasa ajal rahvale suunatud teavitamise viisides. Enam-vähem samast ajast on olemas kuninglik 21. novembriga 1555 dateeritud kiri Savonlinna lääni elanikele, mis käsitles sõjaohtu ja abinõude kasutuselevõtmist sellega seoses. Kiri on säilinud kahe soomekeelse koopiana Savonlinna linnuseülema Ture Pedersson Bielkeni koopiaraamatus (avaldatud Grotenfelt 1912: 5-8). See oli tõenäoliselt esimene soome keelde tõlgitud korraldus, küll trükkimata, kuid muidu igati tüüpiline.

Trükitud soomekeelsed korraldused olid alguses väga haruldased. Esimene neist oli ilmselt suuremõõduline plakat hobupostijaamade ja küüdikohustuse kohta, mille kuningas Johan III andis 1. detsembril 1584 (Kilpi 1924, nr 28, Adde 1925, nr 13). Teiseks 16. saj pärit trükitud soomekeelseks korralduseks oli hertsog Karli kohtuprotsessi eeskiri, mis on dateeritud 20. märtsiga 1593 (Kilpi 1924, nr 19, Adde 1925, nr 14, Grotenfelt 1912: 22-30). Ka 17. saj algusest on säilinud paar korralduste soomekeelset tõlget. Üks nendest on Gustav II Adolfi küüdikord 1615. aastast (KK Rv Asetukset, nr 1, Pipping 1967, nr 24). Tunduvalt hilisem on korraldus "Kuningallisen Maijtt:n Placati, Tijondist eli Kymmenexist" 1638. a (KK Rv Asetukset nr 2, Pipping 1967, nr 39). Nende nelja kõige vanema korralduse tõlkijat ei teata. Teemad on väga konkreetsed: kuidas valmistuda sõjaks, kuidas pidi olema korraldatud talupoegade küüdikohustus, milline on kohtukorraldus ja kuidas toimus maksustamine.

Kuid juba 1640. aastate alguses astus areenile agar korralduste soomendaja - seaduselugeja (madalam kohtunik) Hartvig Henriksson Speitz. Ta tõlkis ilmselt omal initsiatiivil Gustav II Adolfi poolt 1621. a antud ulatuslikud sõda puudutavad õiguslikud artiklid soome keelde ja avaldas need 1642. a trükisena, kus olid paralleelselt esitatud nii rootsikeelne algtekst kui ka selle soomekeelne tõlge (Pipping 1967, nr 44). 
Umbes samal ajal riiginõukogule saadetud kirjas teatab Speitz, et ta oli "ise tõlkinud sõjaparagrahvid soome keelde ja nüüd hiljuti, arvatavasti Rootsi valitsuse armuliseks meeleheaks, lasknud need oma kulul ka soome keeles trükkida" (SRA Bibliographica 8). Põhjus oli see, et tavalised rootsi keelt mitteoskavad sõdurid ei satuks seaduste mittetundmise tõttu sellisesse olukorda, et nad viiakse"... nii kui varem on juhtunud - oma kuritegude pärast tapetavaks kui lambad või veised". Seejärel tõlkis Speitz 1643. a soome keelde ka veel ulatusliku kogu mäetööndust puudutavaid korraldusi (KK Rv Asetukset, nr 3, Rapola 1935: 344-353). See oli mõeldud kasutamiseks Bergslageni kaevanduspiirkonnas, kus töötas palju soomlasi. Nii sõja- kui ka mäetöönduse seadustik oli üsna keeruline, mistõttu tõlked olid tõepoolest vajalikud. Mõlemad trükiti Stockholmis Peter van Selowi trükikojas, mille ülesandeks oli ilmselt soomekeelsete korralduste ja ka teiste raskete (mh vene- ja kirikuslaavikeelsete) tekstide avaldamine (Rudbeck 1925: 305). Speitzi tõlkeid ei peeta eriti kõrgetasemeliseks, kuid tema töö oligi soome seaduskeele arenematuse tõttu väga raske (Palola 2007: 222-223).

Soomes peeti 17. saj algupoolel omakeelsete korralduste puudumist eriti suureks probleemiks. Põhjus ei olnud nende tekstide kuulajaskonnas, lihtrahvas, kes istus tavaliselt korralikult pinkidel, vaid nende ettelugejates, vaimulikes. Kirikuõpetajate ülesandeks oli tõlkida keeruline rootsikeelne tekst kiirustades ja improviseerides soome veel üsna puudulikku seaduse- ja valitsemiskeelde ning lugeda see ka värskelt rahvale ette. Juhtus sedagi, et rootsikeelne trükitud korraldus saabus kirikusse ainult veidi aega enne selle ettelugemist (Villstrand 2006: 64). Turust on aastatest 1630-1640 teada üsna suur hulk vaimulike tõlgitud käsikirjalisi korraldusi, mis puudutasid nt talupoegade võlakaubandust ja muid tähtsaid teemasid. Neid on säilinud nii Turu magistraadi, toomkapiitli kui ka kindralkuberner Per Brahe arhiivis (KA Adeln och dess gods. Brahe, Per, KB Kungörelser, Melander 1940, Ranta 1975, Korhonen 1924). Tekstid on üsna viimistletud, kuigi paljudel juhtudel võib näha märke kiirustamisest.

Lisaks tõlkijatele sõltus korralduste ilmumine ka trükikojast, sest ainult trükkimine võimaldas avaldada suurt hulka samasisulisi tekste. Trükikojal pidi olema selleks sobiv kuninglik luba, privileeg, mis oli suur ja väärtuslik eelis, sest selliste ametlike trükiste järele oli nõudlus ja nende müümine oli tagatud. Eelmainitud Peter van Selowi trükikoda ei olnud olemasoleva privileegiga rahul ja nõudis ainuõigust ka kõigi soomekeelsete laulu-, palve- ja kooliraamatute trükkimiseks (SRA Bibliographica 8). Välja valiti aga hoopis Peder Waldi trükikoda, mis 
kolis 1642. a Turu linna ja alustas seal tegevust ülikooli, toomkapiitli ja läänikantselei ametliku trükikojana (Luukko 1967: 333). See põhjustas suure muutuse soomekeelsete korralduste avaldamises.

\section{Turu periood korralduste tõlkimisel}

Tähtsaks eelduseks soome keele kasutamisele oli kindralkuberner Per Brahe (ametis 1637-1640 ja 1648-1651) positiivne suhtumine sellesse. "Oma sümpaatiate poolest ei ole ta prantslane või hispaanlane, vaid peab silmas ainult maa kasu," kirjutas itaallasest reisimees Lorenzo Magalotti tema kohta, "ta peab kinni riigi ja aadli vanadest õigustest, armastab vanu kombeid ja vihkab uuendusi, talle meeldivad rootslased ja soomlased, kuid välismaalasi ta väldib" (Aminoff 1944: 139). Mingit vahet Rootsi ja Soome vahel Per Brahe ei näinud ja soome keelgi sobis talle kommunikatsioonivahendiks suurepäraselt.

Turus algas seetõttu 1640. aastatel korralduste süstemaatiline tõlkimine soome keelde, mille ulatusest ei ole arhiivide (läänivalitsus, toomkapiitel ja linna arhiiv) hävimise tõttu tulekahjudes $(1661,1827)$ võimalik täielikku selgust saada. Võib arvata, nagu Arvi Korhonen (1924: 44) on oletanud, et piiskopkonna toomkapiitel toimis omalaadse tõlkebüroona. Helsingi ülikooli raamatukogu (praegune Kansalliskirjasto) soomekeelsete korralduste kogus on umbes 170 sellist kuninglikku korraldust, mis on trükitud ajavahemikul 1645-1713 Turus.

Need korraldused jagunevad ajateljel üsna ebaühtlaselt ja tundub, et vilkam publitseerimistegevus algas alles 1660. aastatel. Tekstidesse tõlkija nime enamasti ei lisatud, see on märgitud vaid erandkorras. "Kuningallisen Maij:tin Krogarein ja Gästgifwarein Ordning" aastast 1649 kannab siiski esilehel märkust, et selle tõlkijateks on "Matthias Johanin Pojcan" ja "Anders Jacoin Pojca Äjmän” (KK Rv Asetukset nr 8, Henriksson 1950: 1). Viimati mainitud isik, kammerfiskaal Anders Jakobsson Äimä on hästi tuntud ning on teada, et ta jagas oma tõlget Pohjanmaal (rts Österbotten) aastail 1649-1650 sedavõrd heldekäeliselt, et kogu trükk sai otsa.

Edaspidi olid tõlkijad ülikoolist - oli ju Turu saanud 1640. aastal oma ülikooli, kus tegeleti kohaliku patriotismi vaimus ka soome keelega. Tähtsam tõlkijate seast oli kahtlemata Erik Justander, keelevirtuoos ja üks varasemaid kirjanikke, kes kasutas soome keelt kõikides kirjanduse liikides. Justander tegutses kõrvalametis korralduste tõlkijana alates 1655. a, mil ta sai poeesia professoriks, kuni 1667. a, mil ta sai kirikuõpetaja koha. Ta soomendas umbes nelikümmend Kuningliku Majesteedi 
korralduse teksti (Pitkäranta 2004: 527-528, vt ka KK Rv Asetukset nr 41-42, Pipping 1967, nr 65, Aminoff 1944: 115). Justander kirjutas 1666. a novembris Per Brahele, et ta oli "transfereerinud ja tõlkinud soome keelde kõik need kuninglikud plakatid, korraldused ja eeskirjad, mida nendel aastatel oli välja antud nii suurel arvul" ja et ta "ei olnud saanud selle töö eest mitte mingisugust palka" (Schybergson 1938: 91). Justanderi järglaseks korralduste soomendamisel sai professor Martin Miltopaeus, kelle tööks oli mh 1671. a palvepäeva plakati tõlge (Pipping 1967, nr 162). Pärast teda tegutsesid soomendajatena kaks Lauraeusenimelist venda (Blomstedt ja Matinolli 1963: 26).

Korraldused muutusid sisu poolest aja jooksul üha mitmekesisemaks. Juba 1647 ilmus esimene palvepäeva plakat - küll veel Stockholmis trükituna - ja seejärel muutus see korralduse tüüp tavaliseks (KK Rv Asetukset nr 5, Koskenvesa 1969:163). Suurem osa korraldustest on nii sisu kui ka keele poolest tunduvalt argisemad kui palvepäevaplakatid. Nad sisaldasid kauplemist, põllumajandust ja metsandust puudutavaid juhtnööre, keelde eri ülesastumiste jaoks, ajutisi vabastusi eri rühmade jaoks. Kuigi enamasti puudutasid nad tervet riiki, oli ka kohalikke korraldusi, nt 1669. a antud korraldus vilja viimise kohta Soome ja Pohjanmaale (KK Rv Asetukset nr 49, Pipping 1967, nr 147). Kuid soomendati ka korraldusi, mis ei olnud mitte mingil moel seotud rahvaliku elulaadiga, nagu nt keeld pidada duelle või teadaanne, millega keelati luksus aadlike seas ristimiste, pulmade ja matusetalituste puhul (Pipping 1967, nr 105, KK Rv Asetukset nr 38). Seega ilmneb, et soomekeelsel lihtrahval olid Rootsi suurriigi aja lõpul üsnagi head teadmised neid endid puudutavate korralduste kohta ja veidi aimu ka teiste seisuste elust. Ei saa väita, et neid oleks emamaa rahvaga võrreldes kõrvale jäetud.

Üks korralduste avaldamisega seotud probleem oli soome keelt piisavalt tundva trükikoja leidmine. Turus kättevõidetud privileeg siirdus Peder Waldi trükikojalt Johan Winteri trükikojale. Winter sai 1681. a uhke tiitli "Kuningliku Majesteedi raamatutrükkal Soome vürstiriigis" (SRA Kanslikollegiets kansliarkiv E XIII:13, Gardberg 1948: 168-169). Privileeg siirdus müügi kaudu Henrik Kristoffer Merckellile, kes jätkas 18. saj alguses Winteri tööd. Rootsikeelsed originaalid trükiti sel ajal Stockholmis tegutsenud Niclas Wankijffi ettevõttes, millel oli õigus välja anda kõiksuguseid korraldusi (SRA Bibliographica 8). See oli riigi tegelik kuninglik trükikoda. Rootsikeelsete korralduste levitamine pärast trükkimist oli sel ajal Riigiarhiivi ülesanne (Bergh 1916: 403-404). Nende asjade eest hoolitses praktikas arhiivi aktuaar Johan 
Schmedeman, kelle ülesandeks oli 1687. a lugeda korralduste korrektuuri ja hoolitseda nende laialivedamise eest (SRA Bibliographica 8).

Stockholmist saabusid seega algtekstid Turu linna, kus need tõlgiti ja trükiti. Kes aga valis tõlgitavad korraldused? Tundub, et see oli Turu piikopkonna toomkapiitli ülesanne, sest ettelugemine toimus kirikutes. Piiskop Johannes Gezelius kirjutas igatahes 1709. a Stockholmi Kantseleikolleegiumile, et tõlkeid peaks tegema veelgi rohkem, sest nii mõnedki tähtsad korraldused olid olemas ainult rootsi keeles. Eriti lapsetapmist, piraatlust ja metsatulekahjusid puudutavad korraldused oleks vaja kiiremas korras soomekeelsetena kasutusele võtta (SRA Kanslikollegiets kansliarkiv E XII: 15). Üks märge näitab siiski, et lapsetapmist käsitlev plakat oli küll soomekeelsena olemas, kuid oli toomkapiitli laost juba 1700. a otsa saanud (Ranta 1975: 800).

\section{Korraldused naasevad Stockholmi}

Kui venelased jõudsid põhjasõja ajal 1713. a Turu linna, oli soome trükkal Henrik Kristoffer Merckell juba jõudnud lastida oma trükimasinad ja metallist kirjatähed ning töötajad laeva, millega trükikoda põgenes Stockholmi. Viimaseks tööks, mille ta enne vaenlase saabumist jagamiseks laiali saatis, oli 1713. a palvepäeva plakat (KK Rv Asetukset nr 38, Pipping 1967, nr 430). Merckell ei naasnud pärast rahu saabumist 1721. a Soome, vaid jäi Stockholmi, kuid säilitas soome trükkali privileegi. Selle kinnitas Kuninglik Majesteet 1725. a (SRA Kanslikollegiets kansliarkiv E XIII: 13).

See seik põhjustas Rootsi aja lõpus suuri raskusi korralduste soomendamisel ja levitamisel. Pärast põhjasõda, aastatel 1723-1729 tegutses tõlkijana Stockholmi soome koguduse kirikuõpetaja Johan Forsskål, kuid tema tegevus oli ajutine (SRA Kanslikollegiets kansliarkiv E IV: 9, Murray 1954: 120-121). Merckelli lesk kurtis 1730. aastatel, et Stockholmis ei olnud mitte kedagi peale soomekeelse kirikuõpetaja, kes oleks osanud soomendada, kuid et tollel oli ka rohkesti muid töid, keeldus ta korralduste tõlkimisest. Ka Merckelli sellid ei osanud piisavalt soome keelt ja tegid seetõttu hulgaliselt trükivigu.

Aeg oli siis hoopis teine kui suurriigi ajal. Enam-vähem kõik asjad korraldati nüüd riigipäevadel ja juba 1726.-1727. a seisuste koosolekul olid Pohjois-Pohjanmaa (rts Nordösterbotten) talupojad tõstnud korralduste küsimuse esile, nõudes eraldi soome keele tõlkija ametikoha loomist riigi pealinna. Järgmisel, 1734. a riigipäeval rõhutas Turu piiskopkonna vaimulikkond, et kolmandik riigi alamatest vajaksid 
soomendaja teenuseid ning Porvoo piiskopkonna vaimulikud ja kogu Soome talupoegade seisus ühines selle algatusega. Ettepanek viiski selleni, et raamatukoguhoidja Johan Mathesius nimetati 1735. a Kantseleikolleegiumi soome keele tõlkijaks 300 hõbetaalri suuruse aastapalgaga. Mõte oli, et kõik kuninglikud plakatid oleks edaspidi olemas ka soome keeles (Lehtinen 1955: 398).

Soome keele tõlkijad on põhjalikult välja selgitanud Einar W. Juva (1946). Nendeks olid ajalises järjekorras Johan Mathesius (1735-1741), Kristoffer Adrian Rosenmüller (1741-1750), Samuel Salin (17501762), David Gottfrid Heintzius (1762-1768), Abraham Lind (17681785), Henrik Reinhold Gummer (1785-1803) ja Henrik Forshäll (1804-1809). Kõik peale ühe olid haritud, ülikoolis õppinud mehed, kes soomendasid sadu korraldusi. Ainuke erand, Kristoffer Adrian Rosenmüller, ei osanud soome keelt piisavalt ja oli saanud ameti ainult sel põhjusel, et oli aadlik. Talle võeti asetäitja ja see, Samuel Salin, sai 1750. a ise koosseisulise tõlkija ametisse ning kujunes ajajärgu kõige usinamaks soomendajaks. Tõlgid abistasid ka Soomest saabunud talupoegadest riigipäeva liikmeid, seda nii suulises tõlkes kui ka ametlike kirjade koostamisel.

Kuna tõlkimis- ja trükkimiskohaks oli Stockholm, siis põhjustas see tähelepanuväärset aeglust ja raskusi võrreldes varasema ajaga, mil tegevus oli toimunud ilma probleemideta Turus. Turust nõutigi kogu 18. saj jooksul endale tagasi õigust välja valida, tõlkida, trükkida ja levitada Kuningliku Majesteedi korraldusi. Kõige pingelisemaks muutus see küsimus just palvepäeva plakatite puhul, sest nende tõlgetest leiti juba 1733. a suuri vigu, mis juhtisid lihtsa rahva mõtted eksiteele (SRA Kanslikollegiets kansliarkiv E XIII: 12). Pika ja mitmeetapilise riiu järel otsustati 1747. a, et palvepäevaplakatid trükitaks edaspidi Turus ja seda just sel põhjusel, et Stockholmist tulnud saadetised olid sageli hilinenud. Palvepäevaplakatid olid nimelt korralduste seas kõige rohkem teatud ajahetkega seotud. Arve tasus ülekandena Turu trükikojale Merckelli trükikoda riigi pealinnast (SRA Kanslikollegiets kansliarkiv E XIII: 12). See muidugi ei meeldinud Merckelli pärijatele ja seetõttu küdes riid palvepäevaplakatite maksmise asjus Stockholmi ja Turu vahel aastakümneid. Lõpuks läks võit viimasele ja palvepäevaplakatid anti Rootsi võimu lõpuaegadel täielikult Turu trükikoja korraldada.

Tõlgitavate korralduste tekstide väljavalimine oligi Rootsi aja lõpuperioodil üsna problemaatiline. Pippingi avaldatud bibliograafia järgi oli tõlketekstide arv 700-800, mis jagunes 75 aasta peale. See vastab umbes neljandikule rootsikeelsetest tekstidest. Tõlgete ajaline hajumine on suur. Nii nt soomendati 1765. a ainult kuus korraldust 87-st, 
kuid juba järgmisel, 1766. a tõlgiti 41 korraldust 139-st. Kui võrrelda Pippingi bibliograafiat rootsi Arstrycket'iga ja sellest tehtud loeteludega, on valiku taga raske mingit süsteemi näha (Pipping 1967: 247-257, SRA Ämbetsarkivet G I:1).

Rootsi aja lõpus muutus olukord lihtsamaks. Nimelt avaldati 1774. a rootsi keeles kokkuvõte kõikidest korduvalt loetavatest korraldustest ja see tõlgiti soome keelde 1800. a (Sammandrag 1774). Tundub, et Soome vaimulikele oli see suureks abiks.

\section{Korralduste tähtsus soome kirjakeele kujunemisele}

Soome kirjakeel sündis tõeliselt 19. saj, kui Soomest oli Porvoo maapäeval 1809. a moodustatud omaette riik Vene keisririigi koosseisus. Alles pärast seda sai Soome ühtse geograafilise territooriumi, mida piiras läänes Hamina rahuga 1809. a Rootsiga kehtestatud piir ja idas nn Vana Soome liitmisega 1811.-1812. a tekkinud piir Venemaaga (piiri kohta lähemalt Tarkiainen 2009: 379-402).

Oma riik täitus vähehaaval rahvusliku vaimuga, mis oli hoopis teisel moel jõuline kui Turu ülikooli ringkondades 18. saj mõju avaldanud fennofiilia. Herderi ja Hegeli aated rõhutasid keele tähtsust rahva kallima aardena, ja kui agarad fennomaanid seejärel leidsid selle suure rahvalaulude varasalve, mis oli tundmatuna uinunud Karjalas ja Ingerimaal, ei tundunud rahvuslikul vaimustusel olevat mingeid piire. "Kalevala" ja "Kanteletar" äratasid ka soovi arendada soome keel täielikuks valitsemis- ja kultuurkeeleks. Sellesse oli vaja tingimata võtta elemente mitte ainult vanast kirikusoome keelest, vaid ka Ida-Soome murretest, laulude õigest emakeelest.

Keskseks kirjakeele loomisel oli puristlik suhtumine võõrastest keeltest võetud laensõnadesse. Soome keelde oli juba keskajal ja 16. saj laenatud rootsi keelest ja selle vahendusel teistest kultuurkeeltest umbes 1100 laensõna, enamasti soome hälaldussüsteemi kohandatud moel (Streng 1915, vt ka Tarkiainen 2010: 233-236), ja järgnevatel sajanditel oli laenamine paisunud veelgi laiaulatuslikumaks. Uued laensõnad olid sageli kohmakad ja nende võõras päritolu oli selgelt näha. 18. saj soomendajad ei tohtinud välja mõelda tundmatuid sõnu, sest nende tekstidel oli juriidiline väärtus eri tüliküsimuste puhul. Selle tulemuseks olid kordused ja eufemismid. Näiteid võib tuua kasvõi Hartvig Henriksson Speitzi töödest. Speitz tõlkis nt sõna ålderman väljendiga "åldermannit eli vanhimmaiset", sõna masugn väljendiga "masuhnin elik pätsin, taikka sulatospaikan" ja general privilegium väljendiga 
"yhteisen oikeuden eli General Privilegiumin" (Tarkiainen 1980: 15-16). Selge on see, et selline kohmakas tõlkepraktika ka pikendas tekste.

Enesestmõistetavalt oli korralduste keel nõrgem kui kaua kiriklikus kasutuses olnud Piibli soome keel, mis oli kahe-kolmesaja aasta jooksul lihvitud selgeks ja pidulikuks, kõikide soomlaste poolt rohkem või vähem mõistetavaks kiriklikuks kirjakeeleks, milles eri laensõnade tõlked olid kinnistunud ja ka rahvakeele varasalvest pärit murdeelemendid omavahel tasakaalus. Kiriklik soome keel oli oma iseloomult puristlik, see tõrjus ilmseid laensõnu.

Korralduste tõlgete rootsipärasusest tulenes, et rahvusliku ärkamise liikumise keelemehed, nagu Karl Niklas Keckman, Wolmar Styrbjörn Schildt-Kilpinen ja eriti Elias Lönnrot, võõrastasid neid, kui arendasid 19. saj uut soome kirjakeelt. Ida-Soome murdeala, kust pärines "Kalevala" luule, tõusis nende silmis suureks väärtuseks, seevastu kui Rootsi aja tõlkijad olid idapoolseid keelejooni vältinud. Soomekeelsed uued sõnad korvasid 19. saj varasemad rootsi ja rahvusvahelised väljendid. Elias Lönnrot lõi inimelu eri valdkondade jaoks umbes tuhat uudissõna, mis põhinesid Lönnroti oma konstruktsioonidel või rahvakeele sõnavaral, ja need kodunesid soome keeles. Ta aktsepteeris ainult selliseid laene, mis olid keeles juba tugevalt juurdunud või vastasid oma häälikuliselt kujult soome sõnadele.

Milliseks kujunes aga varasemate korralduste tõlkijate loodud omalaadse soome kirjakeele saatus? Esmalt peab tõdema, et Rootsi võimu aegsed soomekeelsed korraldused olid uue kirjakeele loomisel keerulised kasutada ka seetõttu, et neid oli raske füüsilisel kujul leida. Väljaanded olid hajali kirikutes ja sellistes taludes, kus varem olid elanud nimismehed, kes pidid neid tundma. Korralduste tekstid püsisid ka rahva mälus kõrvakuulmise järgi. Mitte mingisugust kogutud väljaannet ei olnud olemas. Sellise koostasid eelmainitud Keckman ja tema järel raamatukogu juhataja Fredrik Wilhelm Pipping, kelle suur "Luettelo suomeksi präntätyistä kirjoista" (1856-1857) loetleb terve hulga korraldusi. Suure osa neist oli kogunud rahva seast pärit mees, omalaadne bibliofiil Matti Pohto, matkates Soome risti ja põiki läbi. Loetelu kokku umbes 4000 väljaandest oli Pohto kogunud 3300, muidugi mitte ainult korraldusi, vaid ka muid trükiseid, nt kiriklikke tekste ja juhuluulet (Kalemaa 2006: 760). Hiljem hakkasid korraldusi ja nende sõnavara süstemaatiliselt koguma soome keele uurimisinstitutsioonid, millest valitsevas seisundis on praegu Helsingis tegutsev kodumaiste keelte uurimisinstituut, lühendatult Kotus. 
Siiski ei kadunud vanade soomendajate töö jäljetult. Vana kirjakeele uurimine sai alguse 20. saj keskpaiku eelkõige Martti Rapola tegevuse tulemusel. Tema klassikalises teoses "Vanha kirjasuomi" (esmatrükk 1945, kolmas trükk 1969) on tõstetud esile endise trükikeele sõnavara, uuritud õigekirja kinnistumist, häälikulise kuju arengut, lauseehitust ja poolitamist.

Eriliseks uurimisväärseks jooneks pidas Martti Rapola soome keele kultuurisõnade esmaesinemisi vanas kirjasoome keeles ehk neologisme. Põhjus on siin ilmne - kui uus kultuurisõna ilmus soome keelde, laienes sellega keele kõnelejate maailmapilt ja mõnes osas ka nende kultuurikompetentsus. Esmamainimiste otsimine on siiski raske töö, sest iga uue leiu puhul on põhjust olla umbusklik: kas see oli tõepoolest selle sõna esimene esinemine soome keeles või kuulus sama väljend ehk siiski hoopis varasemasse kihti? Iga üldisesse kasutusse sobivaks tunnistatud kultuurisõna kõrval esines varasemates tekstides suur arv selliseid sõnasepitsusi, mida ei võetud kunagi kultuurkeele osaks. Nendegi uurimine on keeleteaduse huvitav osa.

Sõnade esmamainimise teaduslikule uurimisele pani aluse Martti Rapola teoses "Sanojemme ensiesiintymiä Agricolasta Yrjö Koskiseen" (1960). Tema järgi oli korralduste tekstides neologisme üsna vähe (Rapola 1960: 21). See seisukoht on arusaadav, sest Rapola allikabaas oli nõrk, selleks olid enamasti erilaadsed sõnaraamatud. Vaid kogude kasvades on korralduste osa uudsete sõnade tekkes kasvanud keskseks. Praeguseks ongi etümoloogia uurimine viinud selleni, et korralduste pärandit tuntakse palju paremini. Suur etümoloogia sõnaraamat "Suomen sanojen alkuperä" (kolm osa, 1992-2000) hõlmab umbes 9000 soome keele sõna tekkeloo, ja kuigi sõnad on enamasti leitud mingist sekundaarallikast, viitab register otse ka suurele hulgale kiriklikele tekstidele, soome keelde tõlgitud seadustekstidele, sõnaraamatutele ja kalendritele, aga ka dokumentidele ja korraldustele, kusjuures viimaste kohta kasutatakse lühendit $A s$. Selliseidki sõnu leidub arvukalt.

Veelgi detailsem selgitus korralduste tekstides esinenud sõnade frekventsi kohta tänapäeva soome keele aluspõhjana sisaldub Raimo Jussila teoses "Vanhat sanat. Vanhan kirjasuomen ensiesiintymiä" (1998). Selles põhjapanevas uurimuses, mis katab ajavahemiku 15431810, kasvab korralduste tekstide tähtsus soome kultuurkeele vundamendina veelgi suuremaks. Ainuüksi A-tähe alt leiab kokku 31 neologismi, mille algupära peitub korraldustes. Näiteks sellised nüüdisajal iga päev kasutatavad väljendid nagu alkuaine, allapäin, allekirjoittaa, alusvaate, apuneuvo, apuraha, avuttomuus ja auktoriteetti on esimest korda näinud päevavalgust mõnes Rootsi võimu perioodil trükitud 
korralduses. Seetõttu ei ole põhjust alahinnata vanu plakateid ja korraldusi ning nende soomekeelseid tõlkeid ühe soome keele arengu tegurina.

\section{Korralduste tõlgete ühiskondlik tähtsus}

Veel oleks vaja vastata artikli alguses püstitatud küsimusele, mida korralduste tõlkimine võib näidata rahva algatusvõime ning kohaliku ja kõrgema tasandi suhete kohta. Vaatluse all on olnud keeleliselt erandlik rühm, soomekeelsed, kel oli riigis selgelt oma territoorium ja ühes sellega rahva (det gemena folket, allmogen) ühiskondlik staatus. Kõik Soomes elavad inimesed, kes ei kuulunud lihtrahva hulka, oskasid rootsi keelt. Nõuet tõlkida korraldused soome keelde võib tõlgendada ka protesti mõiste raames. Soomekeelne rahvas ja tema eestvõitlejad ei jäänud rahule olukorraga, et nad on informatsiooni osas viletsamas olukorras kui rootsikeelne rahvas. Reformatsiooniga oli tõlkekeel kõikjal muutunud pühade tekstide keeleks ja selle eeskuju ilmnes nõudmises, et ka ilmalikke tekste on vaja soomendada.

On kerge märgata, et soomekeelseid tekste pidasid väga tähtsaks teatud soome ühiskonnarühmad (vaimulikud, talupojad). Kogu korralduste tõlkimise ajaloo vältel kõlas nõue, et neid tekste oli vaja juurde saada ja võimalikult kiiresti. Kuigi küsimus ei olnud riigi vaatenurgast eriti tähtis, jäädi sellega võrdlemisi kiiresti nõusse. Sellega sai riik oma teavituse ja propaganda viia sellegi rahvaosani, kes ei osanud riigi peamist keelt. Teati, et rootsikeelsed teadaanded ei jõudnud kõikideni ning et teadmatusest võrsus kergesti segadust ja vastupanu. Hea näide otsese rootsi ja luterliku ideoloogia levitamise kohta olid palvepäevaplakatid. Need olid erilise ja omapärase identiteedi oluline ehitusmaterjal Rootsis ja Soomes.

On veel vaja küsida, millisel määral võib korralduste asjus käinud vaidlustes leida natsionalistlikke meeleolusid. Vastuseks on, et mitte mingil määral. Uusaja algupoolel ei olnud olemas mingit keelenatsionalismi, tegemist oli kõige rohkem huviga kohaliku vastu, mida võis märgata eelkõige Turu akadeemia ringkondades. Keelt peeti enamasti ainult kommunikatsioonivahendiks. Haritlaste poolel võidi küll öelda, et soome keel on üsna praktiline ja seda on tegelikult lihtne õppida suure korrapärasuse tõttu, kuid selliste üksikute seisukohtade puhul ei olnud tegemist soome natsionalismiga. Keel muutus identiteedi osaks alles 19. sajandil. 


\title{
Kokkuvõte
}

Korraldused on uurijaid huvitanud kahel põhjusel. Esmalt ilmneb nendest riigi püüd mõjutada rahva seisukohti, lisada seaduste tundmist, lämmatada vastupanu ja tugevdada isamaalist meelsust. Selles osas olid regulaarselt ilmuvad nn palvepäevaplakatid eriti olulised päevakajaliste uudiste Piibli vaimus tõlgendamisel. Korralduste kuulamine, mis oli kohustuslik, lisas rahvale kuulekust, kuid andis samal ajal teadmisi, mida sai ära kasutada oma eesmärkidel. Suurelt osalt just tänu neile valitses Rootsis ja Soomes püsiv ühiskondlik harmoonia, teisiti kui mõnel muul võrreldaval maal.

Teisalt on korraldused olulised soome kirjakeele arengu seisukohalt. Kirikus kujunes reformatsiooni järel välja pidulik Piibli soome keel, kuid ilmalike tekstide keel oli väga vahelduv, rahvakeele väljendusjõust ei piisanud kõikide ühiskondlike küsimuste väljendamiseks. Selles osas tegid soomendajad (kellest mõned on jäänud tundmatuks) ära suure töö, luues suure hulga rootsi keele kõlaga uusi sõnu, mida 19. saj keelepuristid nagu Elias Lönnrot püüdsid kirjakeelest kõrvaldada ja korvata need soome keele hääldusele vastavate neologismidega või idasoomepäraste sõnadega, millele andsid uue väärtuse eelkõige "Kalevala" ja "Kanteletar". Kõiki vanade tõlkijate uudissõnu ei olnud siiski nende kinnistumise tõttu võimalik uutega asendada, mistõttu korralduste keelel on olnud oma oluline osa soome kirjakeele arengus.

\author{
Aadress: \\ Kari Tarkiainen \\ Keijukaistenpolku 9 D 29 \\ 0082 Helsingi, Soome \\ E-post: kari.v.tarkiainen@gmail.com
}

\section{Kirjandus}

Adde, Gustaf (1925) “Äldre finskspråkiga skrifter i svenska bibliotek”. Bok- och bibliotekshistoriska studier tillägnade Isak Collijn, 269-294. Uppsala.

Aminoff, Torsten G (1944) "Per Brahes inställning till Finlands folk och det finska språket”. Historiska och litteraturhistoriska studier 20, 83-146. Skrifter utgivna av Svenska litteratursällskapet i Finland 298. Helsingfors.

Bergh, Severin (1916) Svenska riksarkivet 1618-1837. Meddelanden från Svenska Riksarkivet. Ny följd II:5. Stockholm. 
Blomstedt, Yrjö ja Eero Matinolli (1963) Åbo stifts herdaminne 1554-1809. Finska Kyrkohistoriska Samfundets handlingar 67:1.

Forssberg, Anna Maria (2005) Att hålla folket på gott humör. Informationsspridning, krigspropaganda och mobilisering i Sverige 1655-1680. Stockholm Studies in History 80. Stockholm.

Gardberg, Carl-Rudolf (1948) Boktrycket i Finland intill freden i Nystad. Helsingfors.

Grotenfelt, Kustavi (1912) Suomenkielisiä historiallisia asiakirjoja Ruotsin vallan ajalta vuosina 1548-1809. Acta Historica Fennica. Helsinki.

Henriksson, Karl-Erik (1950) "Kolme suomenkielistä asetusta 1600-luvulta". Bibliophilos 1, 1-3. Helsinki.

Jussila, Raimo (1998) Vanhat sanat. Vanhan kirjakielen ensiesiintymiä. Suomalaisen Kirjallisuuden Seuran toimituksia 696. Helsinki.

Juva, Einar W. (1946) “Suomen kielen translaattoreita Ruotsin vallan viimeisenä vuosisatana”. Historiallinen Aikakauskirja 1946, 194-221.

Kalemaa, Kalevi (2006) "Pohto, Matti (1817-1857). Kirjojenkerääjä, kirjansitoja, lahjoittaja”. Suomen Kansallisbiografia 7, 760. Suomalaisen Kirjallisuuden Seura. Helsinki.

Kepsu, Kasper (2014) Den besvärliga provinsen. Reduktio, skattearrendering och bondeoroligheter i det svenska Ingermanland under slutet av 1600-talet. Bidrag till kännedom av Finlands natur och folk 193. Helsingfors.

Kilpi, Volter (1924) "Suomenkielisen kirjallisuuden varhaispainokset vuoteen 1642". Historiallisia tutkimuksia Artturi H. Virkkusen kunniaksi hänen täyttäessään 60 vuotta, 63-103. Toimittanut Turun Historiallinen Yhdistys. Turku.

Korhonen, Arvi (1924) "Kaksi suomenkielistä julistusta 30-vuotisen sodan ajalta". Virittäjä, 43-45.

Koskenvesa, Esko (1969) "Rukouspäiväjulistusten antaminen Suomessa kustavilaisen ajan lopulla ja autonomian ajan alussa". Historiallinen Arkisto 64, 163-183. Helsinki.

Lehtinen, Erkki (1955) "Vieras virkakieli ja suomalaiset talonpojat n. 1650-1735". Historiallinen Arkisto 55, 363-408. Helsinki.

Linde, Martin (2000) Statsmakt och bondemotstånd. Allmoge och överhet under stora nordiska kriget. Studia Historica Upsaliensia 194. Uppsala.

Luukko, Armas (1967) Suomen historia 1617-1721. WSOY. Porvoo.

Melander, Toini (1940) "Pietari Brahen v. 1638 julkaisema suomenkielinen kuulutus Turun maistraatin arkistossa". Virittäjä, 216-218.

Murray, Robert (1954) Finska församlingen i Stockholm. Stockholm.

Palola, Ari-Pekka (2007) "Speitz, Hartvig Henrikinpoika 1591-1651, lainsuomentaja, lainlukija”. Suomen Kansallisbiografia 9, 222-223. Suomalaisen Kirjallisuuden Seura. Helsinki.

Pipping, Fredrik Wilhelm (1967) Förteckning öfver i tryck utgifna skrifter på finska, äfvensom öfver några andra arbeten, innehållande någon uppsats på detta språk, eller annars ledande till dess kännedom = Luettelo suomeksi präntätyistä kirjoista, kuin myös muutamista muista teoksista, joista löytyy joku kirjoitus suomen kielellä, tahi joku johdatus sitä tuntemaan. 1856-1857. (Suomalaisen kirjallisuuden seuran toimituksia, 20). Faksiimile. Helsinki 1967. 
Pitkäranta, Risto (2004) “Justander, Ericus (1623-1678). Runouden professori, kirjailija, suomentaja”. Suomen Kansallisbiografia 4, 527-528. Suomalaisen Kirjallisuuden Seura. Helsinki.

Ranta, Raimo (1975) Turun kaupungin historia 1600-1721. Turku

Rapola, Martti (1935) "Hartikka Speitzin vuorityö-asetusten suomennos”. Virittäjä, 344-353.

Rapola, Martti (1960) Sanojemme ensiesiintymiä Agricolasta Yrjö Koskiseen. Valikoima. Tietolipas 22. Suomalaisen Kirjallisuuden Seura. Helsinki.

Rapola, Martti (1969) Vanha kirjasuomi. Kolmas painos. Tietolipas 1. Suomalaisen Kirjallisuuden Seura. Helsinki.

Renvall, Pentti (1967) Finsk representation i Sveriges riksdag. Översättning av Claës Gripenberg. Natur och kultur. Stockholm.

Reuterswärd, Elisabeth (2001) Ett massmedium för folket. Studier i de allmänna kungörelsernas funktion i 1700-talets samhälle. Studia Historica Lundensia 2. Lund.

Rudbeck, Gustaf (1925) "Peter van Selow stilgjutare och boktryckare i Stockholm 1618-1648”. Bok- och bibliotekshistoriska studier tillägnade Isak Collijn, 303-334. Uppsala.

Sammandrag af the Kongl. Förordningar, Placater, Bref och Resolutioner, samt andre Publicationer, som å Predik-Stolarna böra ... upläsas. Stockholm 1774.

Schybergson, C. M (1938) Per Brahes brevväxling rörande Åbo Akademi II:2. Skrifter utgivna av Svenska litteratursällskapet i Finland 264. Helsingfors.

Scott, James C. (1985) Weapons of the weak: Everyday forms of peasant resistance. New Haven, London: Yale University Press.

Streng, H. J. (1915) Nuoremmat ruotsalaiset lainasanat vanhemmassa suomen kirjakielessä. Helsinki.

Suomen sanojen alkuperä. Etymologinen sanakirja 1-3. Kotimaisten kielten tutkimuskeskus ja Suomalaisen Kirjallisuuden Seura. Helsinki 1922-2000.

Tarkiainen, Kari (2000) “Kustaa Vaasasta Ruotsin ajan loppuun 1523-1809”. Suomen hallitsijat. Kuninkaat, keisarit ja presidentit, 112-199. Weilin \& Göös. Espoo.

Tarkiainen, Kari (2009) "Luonnollisten rajojen oppi ja David Alopaeuksen osuus Suomen suuriruhtinaskunnan rajojen synnyssä”. Historiallinen Aikakauskirja 4, 379-402. Helsinki.

Tarkiainen, Kari (2010) "Ruotsin kielen vaikutus suomen kieleen". Ruotsin Itämaa. Esihistoriasta Kustaa Vaasaan. Suomen ruotsalainen historia 1, 233-235. Svenska litteratursällskapet i Finland \& Atlantis. Helsinki ja Tukholma.

Tarkiainen, Kari (1980) Ruotsin vallan ajan suomenkielisiä asetuksia. Suomen kieli Ruotsissa. Norden-yhdistys, Suomalais-ruotsalainen kulttuurirahasto, Finnkirja. Tukholma.

Villstrand, Nils Erik (1992) Anpassning eller protest. Lokalsamhället inför utskrivningarna av fotfolk till den svenska krigsmakten 1620-1679. Åbo Akademis förlag. Åbo 1992.

Villstrand, Nils Erik (2006) "Nyheter från prediksstolen”. Signums svenska kyrkohistoria. Frihetstiden. Redaktör Jakob Christensson, 51-68. Bokförlaget Signum. Lund. 


\title{
Kogud ja arhiiviallikad
}

Rahvusarhiiv andmebaas "17. sajandi (kuni 1710) trükised Ajalooarhiivi fondides": http://www.ra.ee/plakatid

Svenska Riksarkivet (SRA), Stockholm

Bibliographica 8

Kanslikollegiets kansliarkiv E IV:9, E IX:24, E XII:15, E XIII:12, 13, 24

Ämbetsarkivet G I:1

Kammararkivet (KA)

Adeln och dess gods. Brahe, Per

Kansalliskirjasto (KK, endine Helsingin Yliopiston kirjasto, HYK), Helsingi

Painatekokoelma. "Rv Asetukset 1615-1670"

Kungliga Biblioteket (KB), Stockholm

Kungörelser af Finlands, Ehstlands etc. generalgouvernörer

\begin{abstract}
Kari Tarkiainen: The state speaks to the people: Ordinances issued in Finnish during the era of Swedish rule. In Sweden, the king and governors issued ordinances since the 16th century that were disseminated by reading them out at public meetings or from the church pulpit. This custom was codified by the ecclesiastical law of 1686 . The reading out of ordinances became a part of the church service and it was compulsory for everyone to listen to them. Since people in Finland, which was the eastern part of the nation, did not understand Swedish, the ordinances started being translated into Finnish, for which reason such texts accounted for about one fourth of all ordinances by the end of the period of Swedish rule. The persons working for the Chancellery Council who translated the texts into Finnish and the royal printing house, which possessed the privilege for printing the ordinances, became the mainstays of this system. The most important of the texts were the placards presented 3-4 times a year proclaiming days of prayer, which included topical news for the church holiday in the light of biblical texts. Ordinances were printed mostly in Turku during the 17th century, but mostly in Stockholm in the 18th century.

In earlier times it was thought that the texts of these ordinances had relatively little meaning for the development of written Finnish, which started proceeding in the 19th century in the direction of purism, rejecting common Swedish idioms from the civilised language of that time. More recent studies of old written Finnish nevertheless indicate that new words and neologisms adopted by ear and created by translators had carried over into popular language to quite a great extent and were transferred from there into contemporary
\end{abstract}


Finnish as well. The demand for texts in Finnish in the eastern part of the nation is not indicative of the national feeling of Finns in the 16th-18th centuries. Instead, the basis for this was the need to ensure the equality of all people before the law. The ordinances were indeed very important socially in developing perception of the law among the broad strata of the population and in adding knowledge of the laws.

Keywords: Swedish legislation, translation, old written Finnish, neologisms, placards declaring days of prayer, the course of a church service, disciplining of the people 